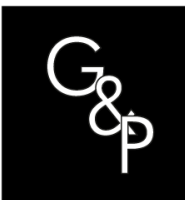

\title{
Criteria analysis for deciding the LTL and FTL modes of transport
}

\author{
Análise de critérios para decisão dos modos de transporte LTL e FTL \\ Diego Armando Soto De La Vega', Paula Horta Lemos ${ }^{1}$, \\ João Eduardo Azevedo Ramos da Silva ${ }^{1}$ (1), José Geraldo Vidal Vieira ${ }^{1}$ (1) \\ ${ }^{1}$ Universidade Federal de São Carlos - UFSCar, Campus Sorocaba, Sorocaba, SP, Brasil. \\ E-mail: die-soto@hotmail.com; paula_lemos_3@hotmail.com; jesilva@ufscar.br; jose-vidal@ufscar.br
}

How to cite: De La Vega, D. A. S., Lemos, P. H., Silva, J. E. A., \& Vieira, J. G. V. (2021). Criteria analysis for deciding the LTL and FTL modes of transport. Gestão \& Produção, 28(2), e5065. https://doi.org/10.1590/1806-9649-2020v28e5065

\begin{abstract}
Choosing between Less Than Truckload ( $L T L)$ and Full Truckload (FTL) is based on a multicriteria decision because it takes into account aspects such as costs and operational efficiency in transportation, handling and stock of goods. The aim of this article is to provide a detailed analysis of the criteria that comprise the LTL and FTL transport decision using a multicriteria methodology that considers decision makers' preferences. The SMARTS method was applied in a telecommunications company that outsources its logistics operation. Results show that the main criteria for choosing LTL shipment are related to the relationship with the customer and the efficiency in the delivery of the freight (reliability of the delivery time). On the other hand, choosing FTL transport requires a high weight given to the criteria regarding benefits and cost of transit inventory. The contribution of the research is to provide a structured and flexible analysis to choose the types of shipment (FTL and FLT) when taking into account the risk aversion of decision makers using a non-optimal approach, but with approximate solutions encompassing several qualitative and quantitative criteria in this choice.
\end{abstract}

Keywords: Supply chain; Distribution problem; Less Than Truckload (LTL) and Full Truckload (FTL); Criteria; Multicriteria Decision Making.

Resumo: A escolha entre os carregamentos via carga incompleta (less than truck-load - LTL) e carga completa (ou Full truck-load - FTL) tem base em uma decisão multicritério, pois leva em consideração aspectos como custos e eficiência operacional no transporte, manuseio e estoque das mercadorias. O objetivo deste artigo é prover uma análise detalhada dos critérios que compõem a decisão de transporte LTL e FTL por meio de uma metodologia multicritério que leva em consideração as preferências dos decisores. Foi aplicado o método SMARTS em uma empresa de telecomunicações que terceiriza a sua operação logística. Os resultados mostram que os principais critérios para a escolha do carregamento LTL se referem ao relacionamento com o cliente e à eficiência na entrega da carga (confiabilidade do tempo de entrega). Por outro lado, a escolha do transporte FTL requer um elevado peso dado aos critérios referentes a benefícios e a custo de estoque em trânsito. A contribuição da pesquisa é prover uma análise estruturada e flexível para escolha dos tipos de carregamento (FTL e FLT) ao levar em consideração a aversão ao risco dos decisores por meio de uma abordagem não ótima, mas com soluções aproximadas englobando vários critérios qualitativos e quantitavos relavantes nesta escolha.

Palavras-chave: Cadeia de suprimento; Problema de distribuição; Tipos de carregamento; Critérios; Tomada de Decisão Multicritério.

\section{Introduction}

The problem of freight distribution via road transport involves a decision between two shipment modes: Full Truckload (FTL) and Less than Truckload (LTL). Costs and customer service time are the most cited in the literature in terms of choosing these two modes of transportation. To contract the FTL mode, the fixed cost is calculated according to the capacity of the rented vehicle, while for the LTL shipment the cost is based on the quantity shipped (weight and volume) and the distance traveled (Rieksts \& Ventura, 2010). FTL transport provides shorter service times, as well as less variability, as this type of transportation directly serves the origin

Received Aug. 17, 2019 - Accepted Dec. 11, 2019

Financial support: This research was funded by the National Council for Scientific and Technological Development (CNPq), Grant numbers 409128-2018-0 and 3099172019-0).

(c) (i) This is an Open Access article distributed under the terms of the Creative Commons Attribution License, which permits

unrestricted use, distribution, and reproduction in any medium, provided the original work is properly cited. 
and destination without additional stops for consolidation. While in LTL transport, consolidation and transhipment centers are visited to group small shipments aiming to increase transportation efficiency.

However, other factors also affect the choice of these modes of transportation and vary according to the sector analyzed. Danielis et al. (2005) evaluated that in chemical product, fiber and machine sectors, the quality of transportation with respect to time, reliability, and risk of loss and damage takes priority over cost. On the other hand, for the electrical equipment sector, research indicated a high preference for the reliability of delivery time, and risk of loss and damage, at the expense of cost. These sectors revealed that costs are not always preferred in choosing the mode and that for finished products the time in transit criterion is highly relevant.

To decide the type of shipment involving multiple criteria, the methods based on MCDM are more indicated for offering an approximate solution, whereby the Analytic Hierarchy Process (AHP) (Wind \& Saaty, 1980) and the Multi-Attribute Utility Theory (MAUT) are the most cited in the literature (Ishizaka \& Nemery, 2013). According to Ho \& Emrouznejad (2009), traditional approaches to optimization generally fail to consider only quantitative criteria in optimization techniques and, on the other hand, it is unfeasible to consider all criteria simultaneously in this type of decision in a single optimization model.

This study proposes a criteria analysis that influences decision making for choosing freight transport modes based on the Simple Multi-Attribute Ranking Technique using the Swings (SMARTS) method (Edwards \& Barron, 1994), within the MAUT approach. The criteria were researched in the literature and the multicriteria model was validated using a case study in a large telecommunications company. As a contribution, this research provides a multicriteria decision hierarchical structure that provides a basis to the in-depth discussion of which criteria are most relevant when choosing between FTL and LTL modes. Therefore, this study can be used by companies in the telecommunications sector for structured and flexible decision making regarding the choice between the two modes of transportation, taking into account risk aversion in the decision.

Section 2 presents a discussion of the relevant criteria in freight distribution according to these modes of transportation and the sector in which they operate. Section 3 presents the research methodology. Section 4 discusses which criteria are most relevant when choosing modes, based on a case study in a telecommunications company. In this section, the utility functions for each criterion are defined, considering risk aversion and the intrinsic preferences of decision makers. Section 5 presents the conclusions, limitations and future work.

\section{Literature review}

The FTL mode refers to a single freight to be transported from the origin to the destination without stopping points (Chu, 2005), involving operations with low fixed costs and maximum vehicle occupancy capacity, as the freight is programmed to meet a specific demand. In the LTL mode, the freight cost is generally much higher than the cost of an FTL freight, since the freight is consolidated along a route distributed in different geographical points, but within the same zone. Therefore, the time from the origin and destination is longer, as the truck makes several stops for loading and unloading at distribution centers to consolidate the freight. To transport small quantities, the LTL mode is usually used and for long distances the FTL is used.

According to Oliveira et al. (2014), selecting the correct way to transport freight can mean significant cost savings for companies and better customer service, based on greater transit time reliability, low delivery error, greater speed and transport security to the final recipient, rapid response in emergency situations, offering documentation and billing services to the customer, among other factors related to customer service, handling and freight handling and strategic factors. Additionally, criteria related to inventory replacement costs can be incorporated into the multicriteria decision, such as maintenance costs, safety stock costs and cost of transit inventory; these are taken into account to define the optimal order quantity or frequency according to the defined stock control policy. Therefore, the criteria can be distinguished into two groups: criteria based on costs and criteria based on operational efficiency.

According to Ballou (2009), the "relevant costs" for the transport problem consist of: transport costs, inventory maintenance costs and transit inventory costs. Transport costs are the sum of the fixed and variable costs. The fixed ones refer to the depreciation of the fleet, salaries and maintenance. Variable costs include fuel, tires, and lubricants, among others. According to Rieksts \& Ventura (2010), in FTL transport there is a fixed cost per shipment of up to a given capacity, however if a shipment less than the available capacity is transported, the cost is charged on the maximum shipment, making it unfeasible to use the FTL mode. In this case, LTL transport is suggested, as there is a unit cost of transportation. Inventory 
maintenance costs, on the other hand, consist of elements such as the value of the inventory that could be invested adds interest, that is, the opportunity for capital, the cost of insurance, obsolescence, losses and other associated risks. In addition to these, the cost of transit inventory is also relevant (Chu, 2005; Meixell \& Norbis, 2008).

The criteria based on operational efficiency can be classified into five categories according to: service level; security in service provision; customer service; handling and handling factor and strategic factor.

The service level consists of the transport lead time, transit time reliability, reliable collection service, low delivery error and service frequency. For FTL shipments, these criteria are better met, as this mode of transportation provides deliveries in less time, with greater reliability in delivery and less variability, as transportation attends from origin to destination without additional stops for consolidation. In LTL shipments, the freight passes through some consolidation and transhipment centers to group freight to increase transport efficiency.

Aguezzoul (2014) defines security in service provision as the stability and good performance of the logistics service provider, which ensures continuity of service and regular updating of the equipment and services that are used in logistics operations. According to Kokkinis et al. (2006), a safe and stable carrier in the market can ensure good performance of the transport and favors the growth of a close and long-term collaboration. On the contrary, entrusting transportation to a company that faces difficulties in stabilizing the market can lead to unforeseen problems, such as using unreliable carriers, delays and even third parties holding goods, such as at customs.

Customer service refers mainly to personal treatment, punctuality and courtesy in the way carriers and service providers interact and introduce themselves to customers. In a study by Kokkinis et al. (2006), it was found that personal treatment contributes to improving the services provided, mainly because of the direct exchange of information and advice between the two parties on specific transport requirements. To improve the efficiency of customer service, many companies have been investing in information technology, which corresponds to the information systems that companies have to facilitate the communication and execution of their customers' logistical operations (Jharkharia \& Shankar, 2007). In some cases, suppliers may allow customers to use their systems for tracking and controlling freight. For FTL transport, it is much easier to coordinate these activities, because the range of clients that must be served per route is smaller, as there is a single client from origin to destination, whereas for the LTL shipments, the difficulties related to communication with customers are more challenging.

According to Aguezzoul (2014), the definition of a handling and handling factor is related to the ease in making changes in loading and unloading operations and the ability to adapt to new customer requirements and circumstances, payment conditions, operations and delivery and guarantee to customers that freight will be delivered smoothly, even when the operation does not go as initially planned due to transport parameters, means of transportation, date of departure, place of delivery, volume of freight, etc. According to Oliveira et al. (2014), this factor is related to sharing the company's culture and values, long-term relationships and flexible rates for loyal customers. It refers to the ability of the customer and the carrier to work together closely to achieve common goals.

The literature review shows that the criteria for choosing FTL and LTL shipment modes of transportation generally focus on low cost, high quality of service and rapid response to emergencies, while LTL focuses on the flexibility of modes of transportation and flexible rates (Swenseth \& Godfrey, 2002) and in managing smaller shipments (Özkaya et al., 2010). In the LTL mode, flexible rates depend on the number of units shipped and price schedules are determined before retailers make a decision; In the FTL mode, prices are fixed by truck, regardless of whether they are fully or partially loaded (Toptal \& Bingöl, 2011). Many studies have analyzed the criteria that influence the mode of choice. McGinnis (1989) and Murphy et al. (1997) compared these criteria in the 1970s, 1980s and 1990s. Meixell \& Norbis (2008) reviewed the studies twenty years later. Most previous studies have shown that the importance of freight rates is not always high compared to service levels, and sustainable initiatives have challenged companies in goods transport (Vieira et al., 2016). The supply chain integration, considering the integration between companies and all third-party logistics, is the most important (Meixell \& Norbis, 2008). Thus, a long-term relationship (Özkaya et al., 2010) can positively influence the choice of FTL or LTL, when there are one or two customers generating business on a larger scale (Toptal \& Bingöl, 2011). According to Özkaya et al. (2010), intangible factors, such as freight desirability, economic value estimation and negotiation power are significant for the choice of transportation mode. Moreover, the long-term relationship allows LTL operators to have a reliable collection service and frequent communication with the operator (Toptal \& Bingöl, 2011). The choice of LTL or FTL carriers will also depend on the local destination, deregulation of the transport market (Murphy et al., 1997) and product sector (Danielis et al., 2005). For example, the electronic sectors have preferences for high quality transport services (short term, reliable delivery and freight security) compared to costs. On the other hand, goods in general have high preferences for low delivery times and low costs. 


\section{Research methodology}

The high number of criteria evaluated in the transportation mode selection process makes it complex. In this scenario, tools and techniques need to be used to select the best way of distribution taking into account the multicriteria nature of the problem. The set of data and criteria were the same used by De La Vega et al. (2018) to develop a decision model involving SMARTS and Goal Programming. However, it is noteworthy that this research is different as it evaluates in detail the importance of the criteria for choosing the FTL and LTL modes.

According to Ehrlich (1996), the success of Decision analysis tools, as support for problems with a single objective, paved the way for studies of more ambitious problems such as decisions with multicriteria, as is the case of this research. The Multiple Attribute Utility Theory (MAUT) methodology resulted as a natural evolution of decision analysis. Consider, for example, the freight distribution problem that involves criteria other than cost and speed, such as coverage and access, ease of making changes, control and tracking, among others (Anaya, 2009). Problems such as these, in which the results are characterized by several criteria, are treated by MAUT more flexibly and that represents the real decision situation, because for each criterion, utility curves are drawn and later these criteria can be compared according to the decision makers' preference.

To address this large number of criteria, studies have revealed the growing use of the multicriteria approach for solving contemporary problems. Aguezzoul (2014) carried out a literature review on criteria and methods for selecting logistics operators through articles published between 1994 and 2013 in important databases. In terms of methods for selecting 3PL, they categorized five groups, which were called: MCDM approach, statistical approach, artificial intelligence, mathematical programming and combined or hybrid methods (Table 1).

Table 1. Solution approaches to multiple criteria problems.

\begin{tabular}{|c|c|c|c|}
\hline Category & Methods & Strong points & Weak points \\
\hline MCDM & $\begin{array}{l}\text { AHP } \\
\text { ANP } \\
\text { TOPSIS } \\
\text { ELETRE } \\
\text { ISM } \\
\text { VIKOR } \\
\text { DEMATEL }\end{array}$ & $\begin{array}{l}\text { (2) They can deal with multiple } \\
\text { qualitative or quantitative criteria. } \\
\text { (3) They consider the dependence } \\
\text { between the criteria. }\end{array}$ & $\begin{array}{l}\text { (1) The weightings assigned to the } \\
\text { criteria depend on human } \\
\text { judgments. } \\
\text { (2) No possibility to include } \\
\text { restrictions on the models. } \\
\text { (3) The construction of comparison } \\
\text { matrices and utility curves is a } \\
\text { tedious and time-consuming task. }\end{array}$ \\
\hline $\begin{array}{l}\text { Statistical } \\
\text { approaches }\end{array}$ & $\begin{array}{l}\text { Correlation methods } \\
\text { Cluster analysis }\end{array}$ & $\begin{array}{l}\text { (1) Allow analysis in large } \\
\text { databases. } \\
\text { (2) They can be applied to complex } \\
\text { problems. }\end{array}$ & $\begin{array}{l}\text { (1) They do not provide any optimal } \\
\text { solution. } \\
\text { (2) No possibility of including } \\
\text { constraints in the model (3) Difficulty } \\
\text { to define "cluster" when the criteria } \\
\text { are highly dependent. }\end{array}$ \\
\hline $\begin{array}{l}\text { Mathematical } \\
\text { Programming }\end{array}$ & $\begin{array}{l}\text { Binary Logit } \\
\text { LP/NLP } \\
\text { MILP }\end{array}$ & $\begin{array}{l}\text { (1) Possibility of introducing } \\
\text { constraints in the model. } \\
\text { (2) They can optimize desired } \\
\text { variables. }\end{array}$ & $\begin{array}{l}\text { (1) Difficulty in measuring qualitative } \\
\text { criteria. } \\
\text { (2) Difficulty in analyzing the results, } \\
\text { in the case of MOP. (3) Computing } \\
\text { the optimal solution can be very } \\
\text { time-consuming in NP-Hard } \\
\text { problems. }\end{array}$ \\
\hline & $\begin{array}{l}\text { MOP } \\
\text { DEA } \\
\text { DP }\end{array}$ & $\begin{array}{l}\text { (1) The criterion does not } \\
\text { necessarily have a common } \\
\text { dimension. }\end{array}$ & \\
\hline $\begin{array}{l}\text { Artificial } \\
\text { Intelligence }\end{array}$ & $\begin{array}{l}\text { Data mining } \\
\text { ANN } \\
\text { Delphi Method }\end{array}$ & $\begin{array}{l}\text { (1) They offer a flexible knowledge } \\
\text { base. } \\
\text { (2) They take qualitative factors into } \\
\text { account. } \\
\text { (3) They allow us to work with } \\
\text { complexities and uncertainty, as } \\
\text { they are designed to operate } \\
\text { similarly to human judgments. }\end{array}$ & $\begin{array}{l}\text { (1) The pool of knowledge and } \\
\text { access to knowledge is difficult. (2) } \\
\text { They can be very expensive. }\end{array}$ \\
\hline
\end{tabular}


The authors found that MCDM approaches are the most widely used for the problem of selecting logistics operators (82\% of cases) and are additionally often integrated with methods of the same category, such as ANN, MIP and DEA. Within the MCDM methods, AHP has been shown to be the most prevalent, due to its ease of use and flexibility to combine with other methods. AHP uses the construction of a hierarchy of criteria (Wind \& Saaty (1980). On the other hand, MAUT, introduced by Keeney \& Raiffa (1976) and simplified by the Single Measure Attribute Rating - SMART, SMARTS and SMARTER methods (Edwards \& Barron, 1994) proved to be one of the most popular methods as an individual approach and that, with the incorporation of the Swing weight method, has revealed efficient results in multicriteria decision analysis. For the development of this research, we opted to implement SMARTS, since the AHP requires more comparisons to be made by the decision maker, often generating inconsistencies in the values.

In order to use the SMARTS tool, which uses swing weights as a method of comparing attributes, the decision maker must assign 100 points to the criterion that can raise the highest possible score, and then this criterion is eliminated from the process. Then, the decision maker consults the remaining criteria and again chooses the criterion he/she would like to raise and assigns a value of less than 100 points, and so on (Mustajoki et al., 2006). For the criteria analysis, this research follows the steps described by Goodwin \& Wright (2014).

For the multicriteria analysis, a case in a company in the telecommunications sector was addressed. The shipper is one of the largest companies in this sector in Brazil and its transport service is totally outsourced, whereby a large percentage of the freight transported is destined to a logistics operator (3PL). This study is based on the transport operations managed by the 3PL.

The research was based on the case study investigation method, which, according to Yin (2010), generalizes the theoretical propositions and not the populations, which is precisely the meaning of its use in this study. In data collection, the triangulation principle defined by Yin (2010) was used to add validity and rigor to the research. Numerical data, such as cost tables and demand history, were obtained from the company's databases and its logistics operator. In addition, three strategic managers of the organization (two logistics supervisors and a senior distribution analyst) participated in the definition and weights of the criteria. About ten meetings, with approximately 4 hours each one, were necessary to formally analyze the problem and carry out the steps, mainly to define the utility curves for each criterion. Technical visits for direct observation at one of the major distribution centers were also carried out.

Due to the difficulty of analyzing all criteria simultaneously for a set of FTL and LTL choice alternatives, and also considering the utility functions of each criterion, VISA® software (Visual Interactive Sensitivity Analysis for Multi-Criteria Decision Making) was used which integrated all stages of the decision-making process. The software also aggregates the utilities in a global value and, thus, suggests an alternative as a final solution to the decision problem. In addition, the quantitative criteria (referring to cost and lead time) were previously optimized (see De La Vega et al., 2018).

\section{Presentation and criteria analysis for choosing FTL and LTL modes}

Table 2 presents the hierarchical decision structure considering the classification suggested by Coulter et al. (1989) for the criteria obtained based on a literature review and based on pre-assessments of relevance made by decision makers.

Table 2. Hierarchical structure for analyzing the criteria that influence decision-making.

\begin{tabular}{lll}
\hline \multicolumn{1}{c}{ Criteria } & \multicolumn{1}{c}{ Criteria level 2 } & \multicolumn{1}{c}{ Criteria level 3 } \\
\hline Relevant costs & & Transport costs \\
Quality of service/benefit & Transit inventory cost \\
& Efficiency & Network Lead Time \\
Operational & Transit time reliability \\
& Reliable collection service \\
& Low delivery error \\
& Service frequency \\
& Security in & Cargo security \\
& Freight transport performance history \\
& Rapid response in emergency situations \\
& Geographical coverage of transport and \\
& access \\
& Documentation and billing services \\
\hline
\end{tabular}


Table 2. Continued...

\begin{tabular}{lll}
\hline Criteria & \multicolumn{1}{c}{ Criteria level 2 } & \multicolumn{1}{c}{ Criteria level 3 } \\
\hline & Customer service & Quality of transport personnel \\
& Cooperation of transport personnel \\
\cline { 2 - 2 } & Frequent communication with the carrier \\
Information technology (IT) & Ease of making changes to shipped freight \\
and Handling & Flexible schedules \\
& Shipment capacity limitations \\
& Ease of loading and unloading operations \\
& Shipment tracking \\
& Compatibility of strategies \\
& Factor & Possibility of long-term relationship \\
& Flexible rates
\end{tabular}

The third level criteria were defined through the respective utility functions of each criterion considering the risk aversion and the intrinsic preferences of the decision makers. These functions made it possible to measure the preference of decision makers from one alternative over another and in relation to each fundamental objective. The curves were drawn using the equivalent certainty method (Goodwin \& Wright, 2014; Varian, 2006) and questionnaires were given to decision makers in consensus. The certaintyequivalent method requires the decision maker to think in terms of $50 / 50$ bets. (see the process in Figure 1).

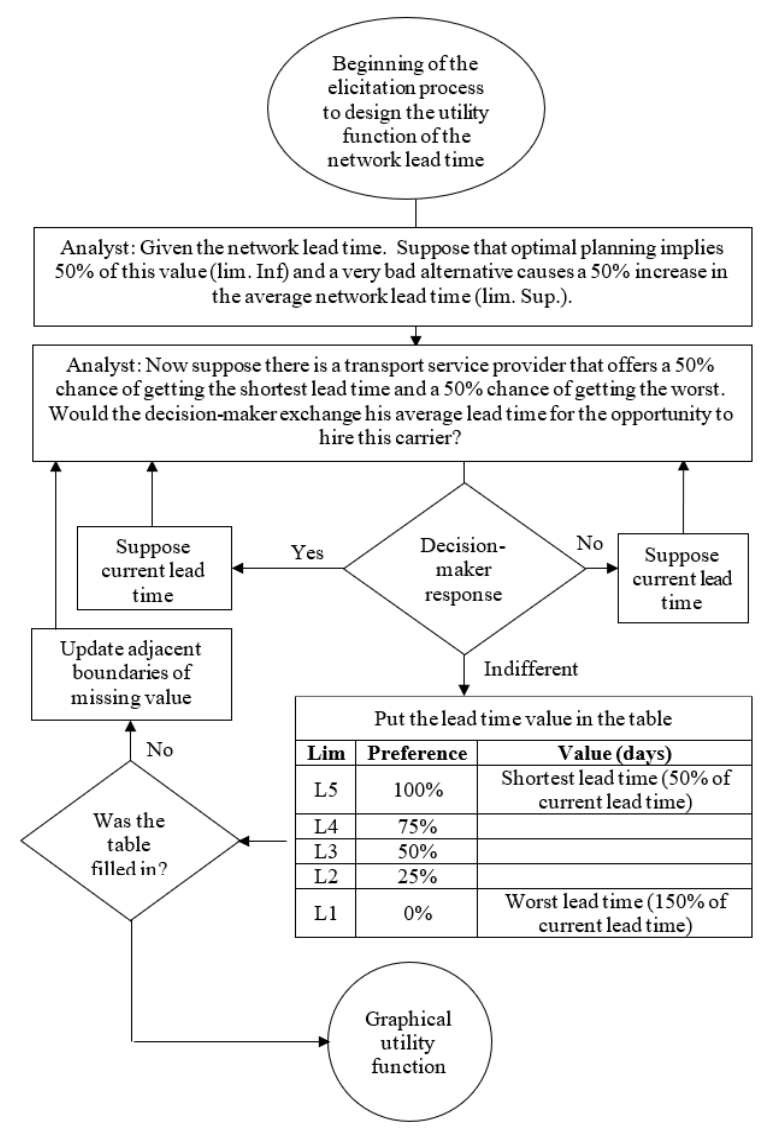

Figure 1. Flowchart for obtaining the utility curve for the Lead time criterion. Note: The utility curves for the other quantitative criteria were obtained in a similar way.

For the "network lead time" criterion, exemplified in Figure 1, the analyst assumes that there is a transport service provider offering a $50 \%$ chance of obtaining the shortest lead time and a $50 \%$ chance of obtaining the worst, therefore the following question is asked: "Would the decision maker trade his/her average current lead time for the opportunity to hire that carrier?" The effect of this procedure is to extract lead times on days that have uses of $0,0.25,0.5,0.75$ and 1 .

Based on the process in Figure 1, the utility curve (Figure 2) is raised. Table 3 presents the values and the respective utility function for the "Network Lead time" criterion. This value indicates, on average, the time that the client's weekly demand takes to be met. 


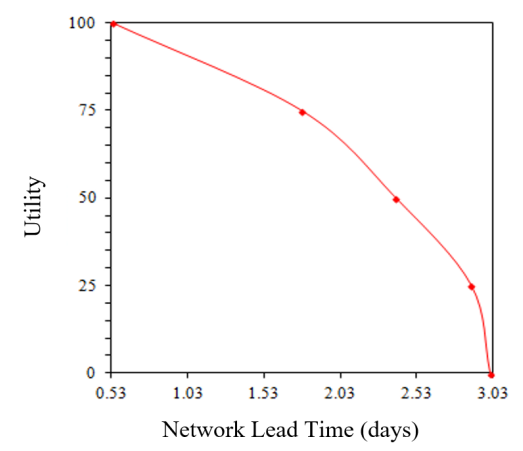

Figure 2. Utility function: Transport lead time.

Table 3. Utility for the network lead time.

\begin{tabular}{cc}
\hline Utility $\boldsymbol{f}(\boldsymbol{x})$ & Average network lead time $(\boldsymbol{x})$ \\
\hline 0 & $x \geq 3.0$ days \\
25 & 2.89 days \\
50 & 2.39 days \\
75 & 1.78 days \\
100 & $x \leq 0.54$ days \\
\hline
\end{tabular}

$f(X)=-12.103 x^{3}+50.448 x^{2}-84.739 x+133.04$

Changes of equal magnitude in the curve domain do not always have the same impact on the utility. It is observed, for example, that a change in lead time from 0.53 days to 3 days generates an approximate loss of utility of 100 units (from 100 to 0 ), while a variation of 0.53 days to 2 days generates a loss of utility of 30 units (from 100 to 70). This behavior reflects the evasive nature of risk in decision makers.

Most of the criteria were considered by the interviewees as qualitative. These criteria have a certain degree of subjectivity, therefore it becomes more difficult to find suitable indicators to measure them. In this case, utility curves were also defined, however, it seeks to evaluate the performance of alternatives directly on the perception of decision-makers and not through indicators.

Using a 5-point scale (0 - Bad; 25 - Poor; 50 - Normal; 75 - Good; 100 - Great) to ask decision makers about the performance of 3 alternatives (100\% FTL, 50\% FTL and $100 \% \mathrm{LTL}$ ), the utility curves for each qualitative criterion could be increased (Appendix A). For example, the utility functions for "Performance history" and "Rapid response in emergency situations" are illustrated in Figures 3 and 4, respectively. The full shipment provides better performance in relation to both criteria mainly due to the short lead time of delivery and the reliability to not exceed the defined deadlines. It can be observed that the preference for the first criterion is linear and for the second non-linear behavior. This indicates that any reduction in the full shipment percentage will result in a proportional decrease in preference for "Performance history" and a non-proportional decrease in preference for "Rapid response in emergency situations". Thus, the shipper can accept a low performance in relation to the performance history but can penalize in a greater degree of utility the low performances in relation to the quick response.

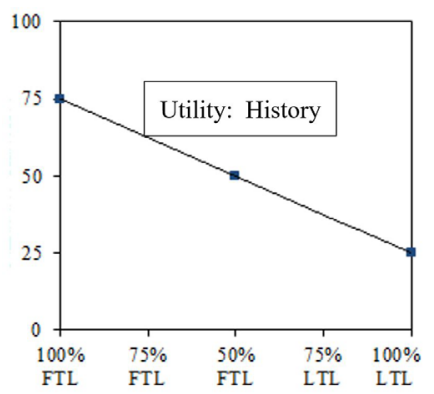

Figure 3. Criteria utility function: performance history. 


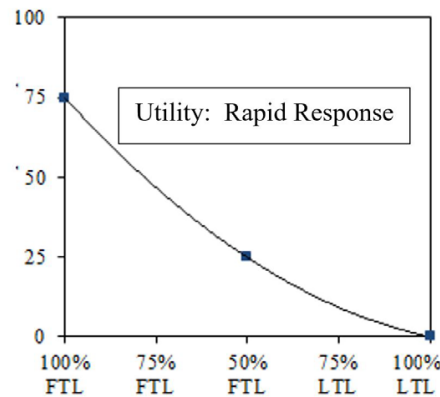

Figure 4. Criteria utility function: rapid response in emergency situations.

Table 4 summarizes the results for the weights given by decision makers to each criterion.

For the first decision maker, preference was observed for cost over benefit. The respondent emphasizes the importance of low inventory levels and concern for the customer. According to this decision maker, the benefit is based on good customer service and, subsequently, this service is largely explained by good information technology and cooperation between the shipper and operator. The second decision maker attributed the same importance to cost and benefit. This person stressed the importance of low transport costs and stock maintenance. Regarding the benefit, the decision maker highlighted the relevance of operational efficiency, mostly represented by the speed and transit time reliability. The third decision maker assessed the cost as more important than the benefit. The decision-maker is equally concerned with low levels of inventory, maintenance and low transport costs. Regarding the benefit, this decision maker is mainly concerned with providing a low risk service to customers, mainly explained by the ability to provide a service without damaging the products.

Table 4. Relative and general weightings for the criteria.

\begin{tabular}{|c|c|c|c|c|c|c|}
\hline \multirow[b]{2}{*}{ Criteria } & \multicolumn{2}{|c|}{ DM1 } & \multicolumn{2}{|c|}{ DM2 } & \multicolumn{2}{|c|}{ DM3 } \\
\hline & $\begin{array}{c}\text { Relative } \\
\text { Weight }\end{array}$ & $\begin{array}{l}\text { General } \\
\text { Weight }\end{array}$ & $\begin{array}{c}\text { Relative } \\
\text { Weight }\end{array}$ & $\begin{array}{l}\text { General } \\
\text { Weight }\end{array}$ & $\begin{array}{c}\text { Relative } \\
\text { Weight }\end{array}$ & $\begin{array}{l}\text { General } \\
\text { Weight }\end{array}$ \\
\hline Relevant costs & $66.7 \%$ & $66.7 \%$ & $50.0 \%$ & $50.0 \%$ & $66.7 \%$ & $66.7 \%$ \\
\hline C. Transport & $34.5 \%$ & $23.0 \%$ & $31.1 \%$ & $15.5 \%$ & $33.3 \%$ & $22.2 \%$ \\
\hline C. Inventory & $54.6 \%$ & $36.5 \%$ & $49.3 \%$ & $24.7 \%$ & $33.3 \%$ & $22.2 \%$ \\
\hline C. Transit Inv. & $10.9 \%$ & $7.2 \%$ & $19.6 \%$ & $9.8 \%$ & $33.3 \%$ & $22.2 \%$ \\
\hline Benefit & $33.3 \%$ & $33.3 \%$ & $50.0 \%$ & $50.0 \%$ & $33.3 \%$ & $33.3 \%$ \\
\hline Operational Efficiency & $23.3 \%$ & $7.8 \%$ & $47.6 \%$ & $23.8 \%$ & $26.1 \%$ & $8.7 \%$ \\
\hline Lead time & $44.5 \%$ & $3.5 \%$ & $33.0 \%$ & $7.8 \%$ & $22.7 \%$ & $2.0 \%$ \\
\hline Reliability & $31.0 \%$ & $2.4 \%$ & $30.3 \%$ & $7.2 \%$ & $22.7 \%$ & $2.0 \%$ \\
\hline Reliable collection & $14.2 \%$ & $1.1 \%$ & $139 \%$ & $3.3 \%$ & $19.7 \%$ & $1.7 \%$ \\
\hline Delivery error & $7.4 \%$ & $0.6 \%$ & $20.2 \%$ & $4.8 \%$ & $19.7 \%$ & $1.7 \%$ \\
\hline Frequency & $2.9 \%$ & $0.2 \%$ & $2.7 \%$ & $0.6 \%$ & $15.2 \%$ & $1.3 \%$ \\
\hline Security in provision & $13.2 \%$ & $4.4 \%$ & $19.1 \%$ & $9.6 \%$ & $32.3 \%$ & $10.8 \%$ \\
\hline Freight security & $8.5 \%$ & $0.4 \%$ & $13.6 \%$ & $1.3 \%$ & $35.7 \%$ & $3.8 \%$ \\
\hline History & $39.6 \%$ & $1.7 \%$ & $19.3 \%$ & $1.8 \%$ & $16.1 \%$ & $1.7 \%$ \\
\hline Responsiveness & $19.3 \%$ & $0.8 \%$ & $17.5 \%$ & $1.7 \%$ & $16.1 \%$ & $1.7 \%$ \\
\hline Coverage/access & $14.3 \%$ & $0.6 \%$ & $21.8 \%$ & $2.1 \%$ & $17.8 \%$ & $1.9 \%$ \\
\hline Documentation & $18.4 \%$ & $0,8 \%$ & $27,8 \%$ & $2.7 \%$ & $14.4 \%$ & $1.5 \%$ \\
\hline Customer service & $48.5 \%$ & $16.2 \%$ & $23.9 \%$ & $11.9 \%$ & $17.4 \%$ & $5.8 \%$ \\
\hline Quality of Personnel & $24.0 \%$ & $3.9 \%$ & $24.6 \%$ & $2.9 \%$ & $33.3 \%$ & $1.9 \%$ \\
\hline Cooperation & $15.2 \%$ & $2.5 \%$ & $21.0 \%$ & $2.5 \%$ & $23.5 \%$ & $1.4 \%$ \\
\hline Communication & $8.5 \%$ & $1.4 \%$ & $24.6 \%$ & $2.9 \%$ & $30.6 \%$ & $1.8 \%$ \\
\hline Information Technology & $52.3 \%$ & $8.5 \%$ & $29.8 \%$ & $3.6 \%$ & $12.5 \%$ & $0.7 \%$ \\
\hline Handling factor & $7.7 \%$ & $2.6 \%$ & $3,4 \%$ & $1.7 \%$ & $13.1 \%$ & $4.4 \%$ \\
\hline Changes & $6.0 \%$ & $0.2 \%$ & $17.5 \%$ & $0.3 \%$ & $25.5 \%$ & $0.9 \%$ \\
\hline Flexible programs & $20.9 \%$ & $0.5 \%$ & $16.9 \%$ & $0.3 \%$ & $24.2 \%$ & $1.1 \%$ \\
\hline Capacity & $16.7 \%$ & $0.4 \%$ & $9.9 \%$ & $0.2 \%$ & $20.8 \%$ & $0.9 \%$ \\
\hline Op. load/unload & $9.0 \%$ & $0.4 \%$ & $9.4 \%$ & $0.2 \%$ & $13.9 \%$ & $0.6 \%$ \\
\hline Tracking & $47.4 \%$ & $1.2 \%$ & $46.3 \%$ & $0.8 \%$ & $15.5 \%$ & $0.7 \%$ \\
\hline Personalized factor & $7.3 \%$ & $2.4 \%$ & $6.1 \%$ & $3.0 \%$ & $11.2 \%$ & $3.7 \%$ \\
\hline Compatibility & $24.9 \%$ & $0.6 \%$ & $25.0 \%$ & $0.8 \%$ & $55.0 \%$ & $2.0 \%$ \\
\hline LP Relationship & $15.7 \%$ & $0.4 \%$ & $25.5 \%$ & $0.8 \%$ & $21.0 \%$ & $0.8 \%$ \\
\hline Flexible rates & $59.4 \%$ & $1.4 \%$ & $50.0 \%$ & $1.5 \%$ & $24.0 \%$ & $0.9 \%$ \\
\hline General inconsistency: & & $4 \%$ & & $5 \%$ & & $3 \%$ \\
\hline
\end{tabular}


The results in Table 4 showed the decision-makers' (DMs) decision to maintain low inventory levels, as these reflect on inventory maintenance costs, consisting of capital opportunity cost, insurance cost, obsolescence and other damage (Chu, 2005).

Regarding the benefit, the "Operational Efficiency" criterion received the highest priority. This indicates, according to Oliveira et al. (2014) that decision-makers are willing to give greater value to companies that seek to make better use of their resources and offer solutions that provide better performance in basic transport operations to ensure effectiveness and efficiency. In particular, the speed and reliability of the time in transit achieved the greatest relevance. The "Customer service" criterion was also prioritized. According to Kokkinis et al. (2006) customers are interested in alternatives capable of ensuring frequent communication and cooperation with the operator, as well as good information technology for greater agility in the processes.

Similar to other works found in the literature, in addition to cost, other criteria were also important. In the work by Jerman et al. (1978), the criteria "Cooperation between transporter and shipment personnel" and "Transport lead time" were also placed at the top of the ranking.

Table 4 also shows the level of consistency in the judgments between the criteria. Therefore, the consistency index proposed by Saaty (2008) was applied to verify the consistency of these judgments. Inconsistency rates below $10 \%$ reflect the coherence of respondents' responses and add greater reliability to their results.

To support the discussion of the criteria regarding their relevance in the choice of LTL and FTL modes, Figure 5 presents the results of the case study developed at the telecommunications company. The figure shows a set of alternatives ( $Y$ axis) for the FTL and LTL shipment distribution problem, based on the overall utility assessments of the criteria according to the grouped preferences of the decision makers.

The results indicated the solution that attributes $30 \%$ of the demand for FTL as the preferred alternative, reaching $77.1 \%$ of the general objective. It is understood that this solution is the most suitable for the purpose of maximizing the performance of the distribution system in relation to the priorities and risk aversion of decision makers.

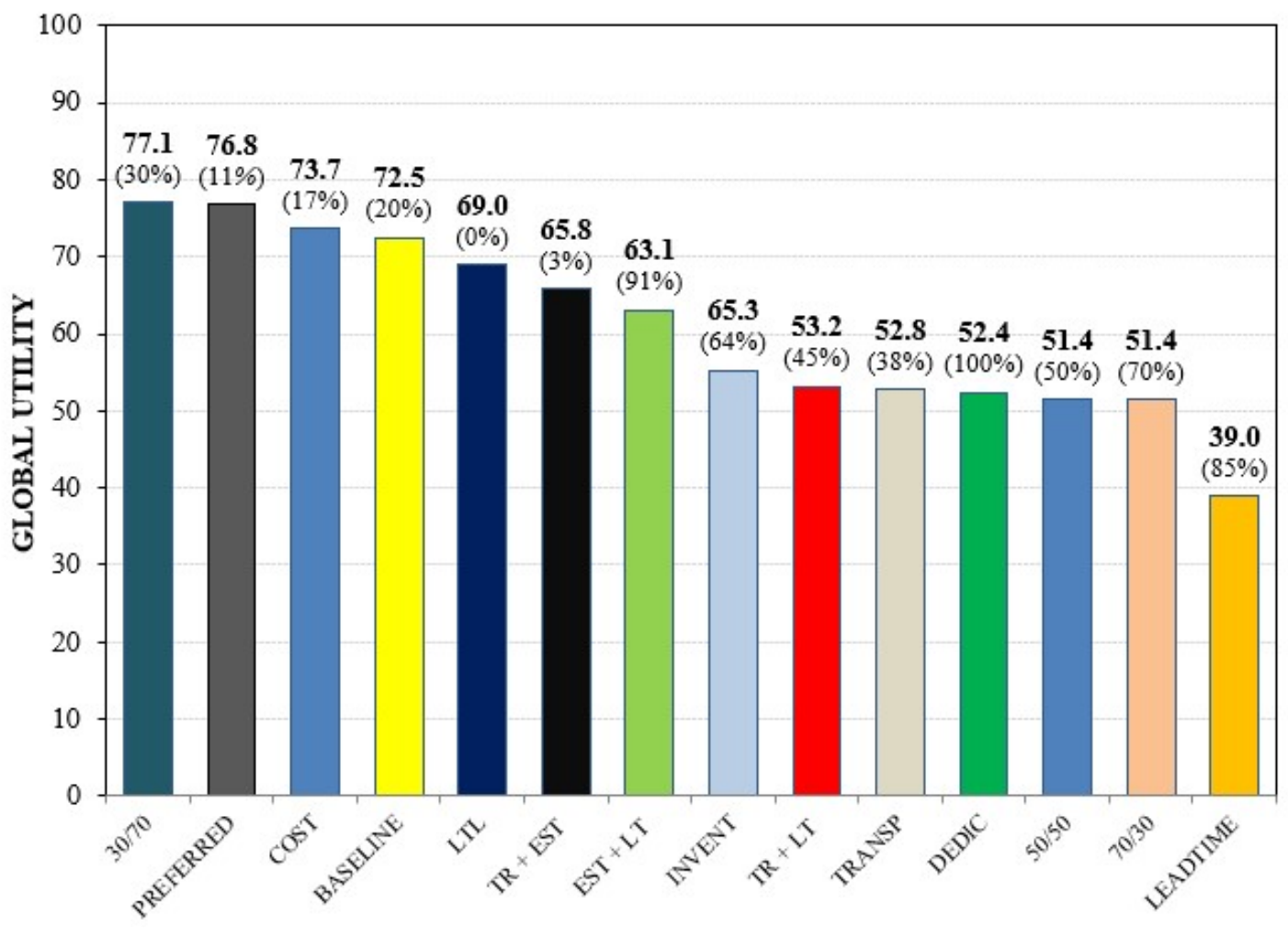

Figure 5. Choice of alternatives for a given global utility of the criteria. Note: All solutions, from left to right, have FTL/LTL values.

Figure 5 also presents the solution generated by the combined judgments of the decision makers (8) as the second most adequate alternative followed by the solution that optimizes costs jointly (4) and the current 
approximate solution of the company (9), as can be seen in De La Vega et al. (2018). It is important to note that, in parentheses, the percentage of demand met with the FTL for each alternative is presented. It can be observed that the most viable solutions assume low percentages of FTL. The least suitable solution is that which optimizes inventory costs in transit or lead time, with a percentage of FTL of $85 \%$ and an overall utility of $39.0 \%$.

Figure 6 also shows the behavior of the solutions in relation to cost and benefit, as well as an approximation to the efficient Pareto frontier.

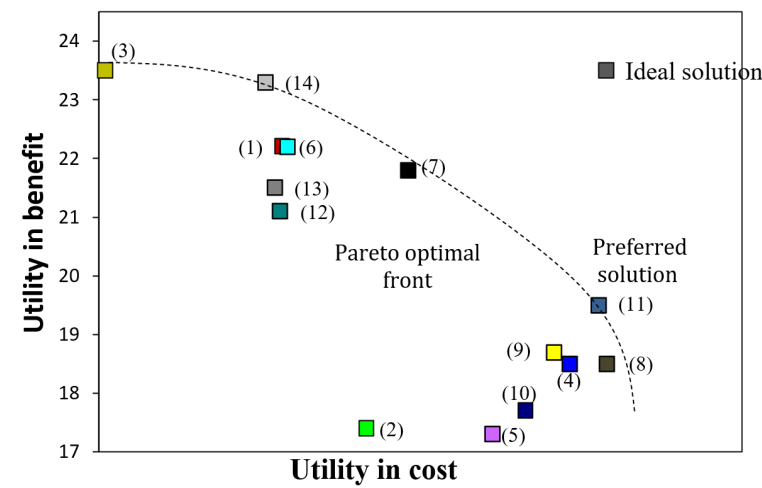

Figure 6. Approach to the efficient Pareto frontier for Cost and Benefit. Note 1: Each solution is related to DESCRIPTION - \%TL/LTL as following: (1) TRANSPORTATION COST - 38/62. (2) INVENTORY COST - 64/36.

(3) LEAD TIME - 85/15. (4) GLOBAL COSTS - 17/83. (5) TRANSPORTATION COST + INVENTORY COST - 3/97.

(6) TRANSPORTATION COST + LEAD TIME - 45/55. (7) INVENTORY COST + LEAD TIME - 91/9. (8) DMs'

SOLUTIONS - 11/89. (9) CURRENT COSTS - 20/80. (10) 0/100. (11) 30/70. (12) 50/50. (13) 70/30. (14) 100/0.

From the results presented in Figures 5 and 6, where they show the priority of choosing the alternatives through the various criteria previously considered in this analysis, we intended to analyze which criteria most contributed to these choices. That is, as the most preferred alternatives allocate a smaller portion to the FTL, at least $30 \%$, as in the case of solution 11 ; followed by solutions $8(11 \%) ; 4(17 \%), 9(20 \%)$ and $10(0 \%)$; the analyses indicate which criteria are most important to choose the LTL mode.

Therefore, Figure 7 presents the result of the sensitivity analyses that allow us to study the variation in weights for all criteria. The triangle $(\boldsymbol{\Delta})$ indicates the relative importance of each criterion compared to others at the same hierarchical level and the cells in each row show the solutions according to the changes made in the weights from 0 to $100 \%$. These sensitivity analyses allow the identification of the most determining criteria for the choice, as well as those with the capacity to significantly alter the suggested solution.

Consider, for example, the criterion "C. Transport", whose relative weight is $34 \%$. If decision makers decided to decrease their importance to less than 15\%, then solution (7) would be more preferred. On the other hand, if the importance of the criterion were increased to $90 \%$, the solution (1) would result as the chosen solution.

Criteria with an exclusive solution are those whose participation is irrelevant to the decision. Observe, for example, the criteria "maintenance factor" and "customization factor". Changes in the weights of these criteria can be made in any direction and magnitude without changing the solution to the problem. Otherwise, it happens with "Costs", "operational efficiency", "Security in the service provision" and "customer service", with the ability to change the choice significantly. Attention is drawn to the fact that it is not only the quantitative criteria, based on costs, that imply significant changes in the percentage in the choice of FTL and LTL alternatives.

In addition, even though the cost has a relative priority greater than the benefit, Figure 7 also shows that major changes in priority would be necessary to change the chosen solution (11). The subcriterion " $\mathrm{C}$.. Transit Inv." would need an increase from $19.8 \%$ to more than $60 \%$ so that the solution (7) exceeds the solution (11) in usefulness. However, the subcriterion "Reliability", a qualitative criterion, needs to become just a little less relevant (from $29 \%$ to $28 \%$ ) in order to make the solution (8) preferred.

Thus, the sensitivity analysis reveals the "cost" criteria as the most relevant criteria with a large weight in the choice, as well as "Reliability", "Documentation", "Communication" and "Frequency" with the ability to change the suggested solution analysis. 


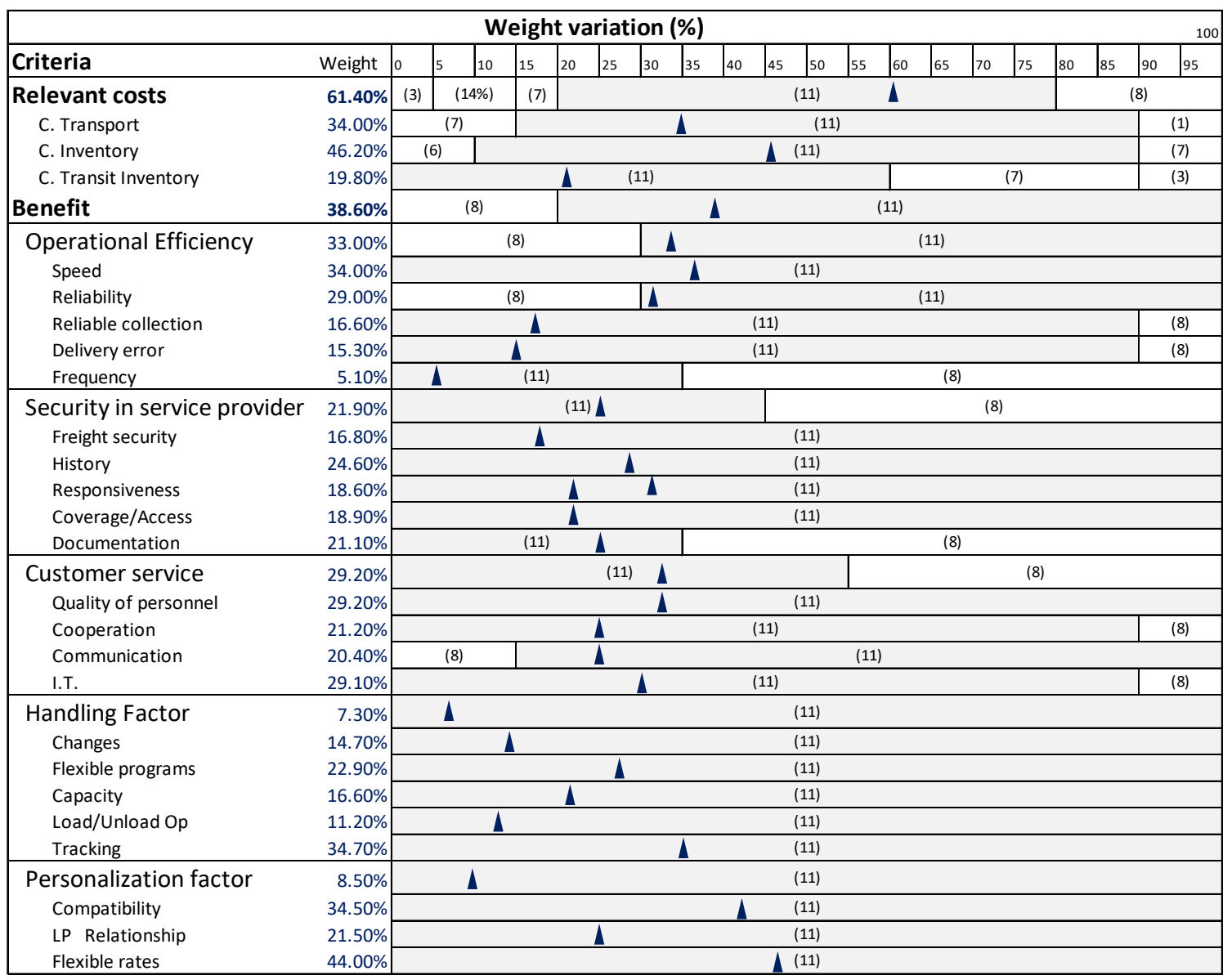

Figure 7. Sensitivity analyses of the criteria weight change.

\section{Conclusion}

The criteria judged by the decision makers showed the differences between the modes of freight transport considered (FTL and LTL) by evaluating several criteria for choosing these modes. In addition to the relevant costs, criteria such as transport lead time, transit time reliability, reputation for the service, ability to provide services that do not damage in transit, flexible fees and documentation and billing services, were repeatedly cited. A research gap was identified regarding researching criteria for the specific selection between modes of transportation of common fleets.

In general, the grouped judgments showed the preference of decision makers for costs over benefits, for the choice of the two types of modes. Costs, already seen as important in the literature for the choice of modes, mainly in terms of comparative weight, proved to be more relevant. However, the benefits have a significant share in the choice of the LTL mode (with 38.6\%), perhaps due to the importance of diversity and combination of all criteria in the choice of final alternatives of percentages of freight transported via LTL and FTL.

It can also be observed that although the costs are the most relevant, the criterion "transit inventory cost" presents a low flexibility in the choice of the percentage of freight transported via LTL or FTL, whereas the criterion "Reliability of delivery time" (belonging to the benefits group) presents itself as highly sensitive to the same choices, that is, they tend to be the most important for choosing the LTL mode. The greater the reliability, the more preferred this mode will be. An interesting fact is that, since the weight of the criterion "Transport cost" (or freight cost) is not so high, compared to the others in its group, this criterion does not negatively influence the choice of the LTL mode, even knowing that this cost is higher when compared to the FTL shipment. This result may reveal that the company already has a freight consolidation route at welldistributed and well-known points along the route, which does not contribute to increasing freight costs to the point of prioritizing transport via FTL.

When considering the chosen alternative (Solution $11-30 \% \mathrm{FTL}$ and $70 \% \mathrm{LTL}$ ), within the groups, the criterion "Inventory maintenance cost" is the most relevant among all costs; followed by the delivery lead time for the group "Operational efficiency"; "Performance history in freight transport within the group"; 
"Security in service provision"; Quality of the personnel that handles transportation within the "Customer Service" group; freight tracking within the group "Freight Handling and Handling"; and Flexible rates within the "Customization of customer service" group. It can be seen, therefore, that most factors refer to the importance given to the relationship with the customer and the efficiency in the delivery of the freight, which is quite justified for an LTL shipment that has several collection points along the route. However, it can be observed that, for all the criteria that comprise the last two groups (Freight Handling and Handling and Customization of customer service) and some criteria of the groups "Security in service provision" and Customer service", there is no sensitivity for choosing a solution other than solution 11 . That is, they are the least relevant when choosing FTL modes.

There is a well-defined set of criteria in the literature, but there was little operationalization. Some authors focus on presenting a list of relevant criteria; however, metrics, indicators or definitions for addressing the choice of LTL and FTL modes are not clearly indicated. This is a limitation in the sense that each criterion can be understood differently for the cases addressed. A second limitation is that the research is based on a single real case, although this case was developed in depth, as it took several hours of work to collect data (primary and secondary); and technical visits to understand the problem and observe logistical operations. Thus, a positive aspect of the research was the participation of key decision makers. These decision-makers must be directly related to the problem, as they are the ones who prioritize the criteria that influence the final choice. However, there may be limitations on the time available to offer judgments with suitability in relation to work.

As future work, we can mention: applications of the hierarchical structure to other cases; cluster the criteria (of greater and lesser relevance) as a result of a survey; apply decision-making models that take into account non-compensatory methods; that is, involving greater cognitive effort, as the decision maker has the difficult task of making trade-offs between the best performance in some criteria and the reduction in the performance of others.

\section{References}

Aguezzoul, A. (2014). Third-party logistics selection problem: a literature review on criteria and methods. Omega, 49, 69-78. http://dx.doi.org/10.1016/j.omega.2014.05.009.

Anaya, J. J. (2009). El transporte de mercancías. (Enfoque logístico de la distribución) (pp. 178). Pozuelo de Alarcón, Madrid, España: ESIC Editorial.

Ballou, R. H. (2009). Gerenciamento da Cadeia de Suprimentos-: Logística Empresarial. Porto Alegre: Bookman Editora.

Chu, C. W. (2005). A heuristic algorithm for the truckload and less-than-truckload problem. European Journal of Operational Research, 165(3), 657-667. http://dx.doi.org/10.1016/j.ejor.2003.08.067.

Coulter, R. L., Darden, W. R., Coulter, M. K., \& Brown, G. (1989). Freight transportation carrier selection criteria: identification of service dimensions for competitive positioning. Journal of Business Research, 19(1), 51-66. http://dx.doi.org/10.1016/0148-2963(89)90040-4.

Danielis, R., Marcucci, E., \& Rotaris, L. (2005). Logistics managers' stated preferences for freight service attributes. Transportation Research Part E, Logistics and Transportation Review, 41(3), 201-215. http://dx.doi.org/10.1016/j.tre.2004.04.003.

De La Vega, D. S., Vieira, J. G. V., Toso, E. A. V., \& de Faria, R. N. (2018). A decision on the truckload and less-thantruckload problem: an approach based on MCDA. International Journal of Production Economics, 195, 132-145. http://dx.doi.org/10.1016/j.ijpe.2017.09.013.

Edwards, W., \& Barron, F. H. (1994). SMARTS and SMARTER: improved simple methods for multiattribute utility measurement. Organizational Behavior and Human Decision Processes, 60(3), 306-325. http://dx.doi.org/10.1006/obhd.1994.1087.

Ehrlich, P. J. (1996). Modelos quantitativos de apoio as decisões: II. Revista de Administração de Empresas, 36(2), 44-52. http://dx.doi.org/10.1590/S0034-75901996000200007.

Goodwin, P., Wright, G. (2014). Decision Analysis for Management Judgment (5a ed.). New York: John Wiley \& Sons.

Ho, W., \& Emrouznejad, A. (2009). Multi-criteria logistics distribution network design using SAS/OR. Expert Systems with Applications, 36(3), 7288-7298. http://dx.doi.org/10.1016/j.eswa.2008.09.012.

Ishizaka, A., \& Nemery, P. (2013). Multi-criteria decision analysis: methods and software. Hoboken: John Wiley \& Sons. http://dx.doi.org/10.1002/9781118644898. 
Jerman, R. E., Anderson, R. D., \& Constantin, J. A. (1978). Shipper versus carrier perceptions of carrier selection variables. International Journal of Physical Distribution \& Materials Management, 9(1), 29-38. http://dx.doi.org/10.1108/eb014435.

Jharkharia, S., \& Shankar, R. (2007). Selection of logistics service provider: an analytic network process (ANP) approach. Omega, 35(3), 274-289. http://dx.doi.org/10.1016/j.omega.2005.06.005.

Keeney, R. L., \& Raiffa, H. (1976). Decision with multiple objectives. Preference and Value Trade-offs (pp. 231232). Cambridge: Cambridge University Press.

Kokkinis, G., Mihiotis, A., \& Pappis, C. P. (2006). Freight forwarding in Greece: services provided and choice criteria. EuroMed Journal of Business, 1(2), 64-81. http://dx.doi.org/10.1108/14502190610750171.

McGinnis, M. A. (1989). A comparative evaluation of freight transportation choice models. Transportation Journal, 29(2), 36-46.

Meixell, M. J., \& Norbis, M. (2008). A review of the transportation mode choice and carrier selection literature. International Journal of Logistics Management, 19(2), 183-211. http://dx.doi.org/10.1108/09574090810895951.

Murphy, P. R., Daley, J. M., \& Hall, P. K. (1997). Carrier selection: do shippers and carriers agreee, or not?. Transportation Research Part E: Logistics and Transportation Review, 33(1), 67-72.

Mustajoki, J., Hämäläinen, R. P., \& Lindstedt, M. R. (2006). Using intervals for global sensitivity and worst-case analyses in multiattribute value trees. European Journal of Operational Research, 174(1), 278-292. http://dx.doi.org/10.1016/j.ejor.2005.02.070.

Oliveira, G. C., No., Librantz, A. H., \& de Sousa, W. C. (2014, September). Logistic Operator Selection with Capacity of Storage and Transport Frozen Product Using Multicriteria Decision. In Proceedings of the IFIP International Conference on Advances in Production Management Systems (pp. 379-386). Berlin, Heidelberg: Springer. http://dx.doi.org/10.1007/978-3-662-44739-0_46.

Özkaya, E., Keskinocak, P., Roshan Joseph, V., \& Weight, R. (2010). Estimating and benchmarking less-thantruckload market rates. Transportation Research Part E, Logistics and Transportation Review, 46(5), 667-682. http://dx.doi.org/10.1016/j.tre.2009.09.004.

Rieksts, B. Q., \& Ventura, J. A. (2010). Two-stage inventory models with a bi-modal transportation cost. Computers \& Operations Research, 37(1), 20-31. http://dx.doi.org/10.1016/j.cor.2009.02.026.

Saaty, T. L. (2008). Decision making with the analytic hierarchy process. International Journal of Services Sciences, 1(1), 83-98. http://dx.doi.org/10.1504/IJSSCI.2008.017590.

Swenseth, S. R., \& Godfrey, M. R. (2002). Incorporating transportation costs into inventory replenishment decisions. International Journal of Production Economics, 77(2), 113-130. http://dx.doi.org/10.1016/S0925-5273(01)00230-4.

Toptal, A., \& Bingöl, S. O. (2011). Transportation pricing of a truckload carrier. European Journal of Operational Research, 214(3), 559-567. http://dx.doi.org/10.1016/j.ejor.2011.05.005.

Varian, H. R. (2006). Microeconomia-princípios básicos. São Paulo: Elsevier Brasil.

Vieira, J. G. V., Mendes, J. V., \& Suyama, S. S. (2016). Shippers and freight operators perceptions of sustainable initiatives. Evaluation and Program Planning, 54, 173-181. http://dx.doi.org/10.1016/j.evalprogplan.2015.07.011. PMid:26227446.

Wind, Y., \& Saaty, T. L. (1980). Marketing applications of the analytic hierarchy process. Management Science, 26(7), 641-658. http://dx.doi.org/10.1287/mnsc.26.7.641.

Yin, R. (2010). Estudo de caso: planejamento e métodos. Porto Alegre: Bookman Editora. 
Appendix A. Utility curves for qualitative criteria.

\begin{tabular}{|c|c|c|}
\hline Criteria & Criteria description and function behavior & $100 \%$ FTL $-100 \%$ LTL \\
\hline $\begin{array}{l}\text { Low delivery } \\
\text { error }\end{array}$ & $\begin{array}{l}\text { In the full load, vehicles are sent directly from the origin. Thus, the quantity, place and delivery } \\
\text { date are checked during boarding and the freight remains intact until reaching its destination. }\end{array}$ & \\
\hline $\begin{array}{l}\text { Reliable } \\
\text { collection }\end{array}$ & $\begin{array}{l}\text { Full loads provide greater reliability for collection, as the shipper can set the collection date/time } \\
\text { and convenience and without usual schedule restrictions on the LTL. }\end{array}$ & \\
\hline $\begin{array}{l}\text { Frequency of } \\
\text { service }\end{array}$ & $\begin{array}{l}\text { LTL is more available. This is explained by the relatively greater opportunity to find the capacity } \\
\text { to transport a shipment concerning the opportunity of having a full truck. }\end{array}$ & \\
\hline Freight security & $\begin{array}{l}\text { In LTL, the products are handled and transferred several times from collection to delivery. This } \\
\text { mode of freight transport is more susceptible to loss, damage or theft. }\end{array}$ & \\
\hline Flexible rates & $\begin{array}{l}\text { The LTL freight table is less susceptible to changes. For the FTL, the freight or price of a vehicle } \\
\text { is defined by specific quotations in terms of supply and demand. }\end{array}$ & \\
\hline History & $\begin{array}{l}\text { The full load provides better performance in the past performance mainly due to the low delivery } \\
\text { lead time and the reliability to not exceed the defined deadlines. }\end{array}$ & \\
\hline Rapid response & The full load responds more quickly in situations where demand has to be met immediately. & \\
\hline Changes & $\begin{array}{l}\text { There are no possibilities for changes on shipped freight. For full loads, a change in volume that } \\
\text { would impact a change in the vehicle used would imply a new schedule. }\end{array}$ & \\
\hline Documentation & $\begin{array}{l}\text { In LTL, the 3PL is responsible for the documentation for control purposes, and the billing is } \\
\text { generated automatically. For a full load, documentation must be done manually by the shipper. }\end{array}$ & \\
\hline Communication & $\begin{array}{l}\text { In the full load, the presence of different carriers makes constant communication between the } \\
\text { shipper and carriers necessary in order to ensure control over the freight. }\end{array}$ & \\
\hline Cooperation & $\begin{array}{l}\text { For LTL, responsibility lies mainly on the } 3 \mathrm{PL} \text {, which has more cooperation and commitment } \\
\text { than autonomous carriers in the case of full freight. }\end{array}$ & \\
\hline $\begin{array}{l}\text { Quality of } \\
\text { personnel }\end{array}$ & $\begin{array}{l}\text { The quality of transportation personnel does not change significantly. Transport personnel can } \\
\text { be the same for both alternatives. }\end{array}$ & \\
\hline Tracking & $\begin{array}{l}\text { Respondents pointed out that there is the same facility because all vehicles regardless of the } \\
\text { type of freight transport are monitored in real time. }\end{array}$ & \\
\hline I.T. & $\begin{array}{l}\text { Information technology of some carriers is not adequate, therefore the full load transportation } \\
\text { mode provides a low performance with respect to this criterion. }\end{array}$ & \\
\hline $\begin{array}{c}\text { Flexible } \\
\text { programming }\end{array}$ & $\begin{array}{l}\text { The full load allows decision makers to decide the time, date, destination and quantity of each } \\
\text { shipment without the usual restrictions in the } L T L \text { schedules. }\end{array}$ & \\
\hline Capacity & $\begin{array}{l}\text { LTL has fewer limitations on the quantities to be transported while for full loads there may be } \\
\text { occasional restrictions on capacity. }\end{array}$ & \\
\hline $\begin{array}{l}\text { Load and } \\
\text { unload op. }\end{array}$ & $\begin{array}{l}\text { For LTL transport, freight operations must be carried out at the operator's logistics hub where } \\
\text { goods from different companies and the shared space can hinder these operations. }\end{array}$ & \\
\hline $\begin{array}{c}\text { Strategic } \\
\text { Compatibility }\end{array}$ & $\begin{array}{l}\text { This is concerned with the suitability or affinity of organizational policies and culture with a } \\
\text { particular mode of transportation. }\end{array}$ & \\
\hline $\begin{array}{l}\text { Long-term } \\
\text { relationship }\end{array}$ & $\begin{array}{l}\text { A FIL offers greater convenience for carriers who are not concerned about the conformation of } \\
\text { shipments or vehicle capacity. As a result, there is a better relationship. }\end{array}$ & \\
\hline $\begin{array}{c}\text { Coverage/ } \\
\text { access }\end{array}$ & $\begin{array}{l}\text { With full freights, the shipper must consider the restrictions of access and times for traffic of } \\
\text { large capacity vehicles in large cities. }\end{array}$ & \\
\hline
\end{tabular}

